\title{
Umbilical cord-derived mesenchymal stem cell transplantation for COVID -19 patients: long-term benefits for lung regeneration
}

\begin{abstract}
Bich Ngoc Vu ${ }^{1, *(1)}$, Van Phuc Pham ${ }^{1,2}$

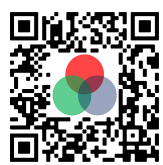

Use your smartphone to scan this QR code and download this article

\section{ABSTRACT}

Coronavirus disease 2019 (COVID-19) has affected hundreds of millions of people worldwide. Currently, mortality due to COVID-19 is significantly reduced by vaccination, antiviral drugs, and some improved treatments. Mesenchymal stem cell (MSC) transplantation-particularly umbilical cordderived MSC (UC-MSC) - has been used as an adjuvant therapy for COVID-19 with some clinical evidence (reviewed in the publication). Moreover, a recent piece published in eBiomedicine (part of The Lancet, https://doi.org/10.1016/j.ebiom.2021.103789) in the previous month showed the longterm effects of UC-MSC transplantation in COVID-19 in a 1-year follow-up randomized, doubleblind, placebo-controlled trial, demonstrating significantly recovered lung lesions and symptoms compared to the control group (i.e., without UC-MSC transplantation). In this commentary, we would like to discuss the value of UC-MSC transplantation for COVID-19 patients based on the results from this study and suggest applying this therapy for COVID-19 patients.
\end{abstract}

${ }^{1}$ Stem Cell Institute, University of Science, Vietnam National University Ho Chi Minh City, Viet Nam

${ }^{2}$ Laboratory of Stem Cell Research and Application, University of Science, Vietnam National University Ho Chi Minh City, Viet Nam

\section{Correspondence}

Bich Ngoc Vu, Stem Cell Institute, University of Science, Vietnam National University Ho Chi Minh City, Viet Nam

Email: ngocvu@sci.edu.vn

History

- Received: Jan 20, 2022

- Accepted: Feb 20, 2022

- Published: Feb 28, 2022

DOI : 0.15419/bmrat.v9i2.725

\section{Check for updates}

\section{Copyright}

(c) Biomedpress. This is an openaccess article distributed under the terms of the Creative Commons Attribution 4.0 International license.

BioMedPress The Open Access Publisher

Key words: Covid-19, Cytokine storm, Lung fibrosis, UC-MSC, Umbilical cord derived mesenchymal stem cell

\section{COMMENT}

Our previous publications about UC-MSCs and their immune modulations include hypothesizing the benefits of UC-MSCs in COVID-19 treatment in $2020^{1}$ and summarizing clinical trials using UC-MSCs for COVID-19 in 2021 ${ }^{2}$. Examining 16 publications covering 395 COVID-19 patients treated with UC-MSCs overall, we found that all publications showed that UC-MSC transplantation is safe, well tolerated, improves COVID-19 symptoms, and significantly decreases mortality ${ }^{2}$.

The latest publication of Lei Shi et al. (2022) in eBiomedicine (part of The Lancet, https://doi.org/10. 1016/j.ebiom.2021.103789) from the previous month about the 1-year follow-up results of a randomized, double-blind, placebo-controlled trial strongly confirmed our observations shared in previous reviews ${ }^{3}$. In this study, there were 65 COVID-19 patients transplanted with UC-MSCs and 35 COVID-19 patients in the placebo group. The authors focused on the effects of UC-MSC transplantation on lung recovery, which was evaluated based on CT images and the 6MWD test at 3, 6, 9, and 12 months. Note that at Month 6, 6 patients (6/51 patients) in the UC-MSC transplantation group had normal CT images; in contrast, none of the patients in the placebo group had normal CT images $(p=0.087)$. At Month 12 , the number of patients with normal CT images increased to 10 in the UC-MSC transplantation group, but not in the placebo group ( $p=0.013)$. The CT imaging results were supported by the 6-MWD tests in both groups. Although the 6-MWD scores gradually increased in both groups over time at $3,6,9$, and 12 months, the patients in the UC-MSC transplantation group increased from $440 \mathrm{~m}$ at Month 3 to $478 \mathrm{~m}$ at Month 12, compared to $420 \mathrm{~m}$ at Month 3 to $441 \mathrm{~m}$ at Month 12 for the placebo group ${ }^{3}$.

These results showed that patients with UC-MSC transplantation displayed good lung function and structure recovery compared to the nontransplantation group. Thus, alongside some previous publications, these observations confirm the roles of UC-MSCs ${ }^{4-7}$. However, whether UC-MSCs can help recover or regenerate damaged lungs in COVID-19 patients is not yet well understood.

With their strong modulation potentials, UC-MSCs can suppress cytokine storms in COVID-19 patients. Accordingly, we proposed some hypotheses regarding the effects of UC-MSCs on lung recovery as a result of minimizing damage during the cytokine storm and inhibiting fibrosis.

Cytokine storms and cytokine release syndrome are life-threatening systemic inflammatory syndromes related to elevated levels of circulating cytokines and immune cell hyperactivation, which can be triggered by various therapies, pathogens, can- 
cers, autoimmune conditions, and monogenic disorders ${ }^{8}$. COVID-19 patients can encounter heterogeneous symptoms ranging from mild fatigue to lifethreatening pneumonia, cytokine storms, and multiorgan failure ${ }^{9}$. Cytokine storms in COVID-19 patients are usually characterized by high concentrations of IL-1 beta, IL-6, IP-10, TNF, interferongamma, macrophage inflammatory protein (MIP) 1 alpha and 1 beta, and VEGF ${ }^{10}$. A high concentration of these cytokines has been significantly associated with pneumonia in COVID-19 patients and the severity of lung injury ${ }^{11}$. UC-MSCs can effectively reduce the level of these cytokines; therefore, they can stop or reduce the effects of cytokine storms in COVID19 patients ${ }^{12-16}$. By this mechanism, lung damage or lung lesions are reduced in the case of UC-MSC transplantation; therefore, lung recovery is expected to be faster and easier in COVID-19 patients transplanted with UC-MSCs. This means that the efficacy of UC-MSC transplantation will be clear if the transplantation is performed before the cytokine storm is done. According to Shcherbak et al. (2021), the basic risk factors for cytokine storms in COVID-19 patients include male sex, over 40 years of age, a positive test result for SARS-CoV-2 RNA, NEWS score dynamics, serum IL-6 greater than $23 \mathrm{pg} / \mathrm{ml}$, serum CRP $50 \mathrm{mg} / \mathrm{L}$ or greater, and absolute lymphocyte count less than $0.72 \times 10^{9} / \mathrm{L}^{17}$. Thus, COVID-19 patients with basic risk factors for cytokine storms should be transplanted with UC-MSCs.

UC-MSCs can inhibit lung fibrosis after damage, making them a treatment of interest given that postCOVID-19 lung fibrosis was observed in approximately half of survivors in the study ${ }^{18}$. In other studies, MSCs showed anti-fibrotic effects on irradiated lungs via endogenous secretion of HGF and PGF2 ${ }^{19}$ and robust regulatory $\mathrm{T}$-cell induction in bleomycin-induced pulmonary fibrosis ${ }^{20}$. In a metaanalysis of preclinical studies, Li et al. (2021) analyzed 24 articles on the treatment of pulmonary fibrosis in an animal model using MSCs; this analysis showed that MSC therapy improved the survival rate and reduced pulmonary fibrosis scores ${ }^{21}$. In a recent review, Chen et al. (2021) summarized 110 publications on the applications of MSCs in pulmonary diseases ${ }^{22}$, including acute/viral pulmonary disease, community-acquired pneumonia (CAP), chronic obstructive pulmonary disease (COPD), bronchopulmonary dysplasia (BPD), interstitial lung diseases (ILD), chronic pulmonary fibrosis, bronchiolitis obliterans syndrome (BOS), and lung cancer. This review confirmed that MSC transplantation is a promising therapeutic approach for treating lung disease ${ }^{22}$. Furthermore, in a case report by Silva et al. (2021), UC-MSC transplantation corresponded to immunomodulatory and anti-fibrotic effects in a critically ill patient with COVID-19 presenting with lung fibrosis ${ }^{23}$.

Based on the current results, UC-MSC transplantation should be considered as an adjuvant treatment in patients at high risk for cytokine storms, which includes those with COVID-19. Indeed, UC-MSC transplantation minimizes the lung damage caused by cytokine storms and inhibits lung fibrosis in postCOVID-19 patients. Although more large studies are required on this topic, the current data about the safety and long-term effects of UC-MSC transplantation for COVID-19 patients are sufficient for this therapy to be considered as an option in such cases.

\section{ABBREVIATIONS}

6-MWD test: The 6-min walk test, COVID-19: Coronavirus disease 2019, CT: Computed tomography, UC-MSC: Umbilical cord derived mesenchymal stem cell

\section{ACKNOWLEDGMENTS}

None.

\section{AUTHOR'S CONTRIBUTIONS}

Authors equally contributed to this work, read and approved the final manuscript.

\section{FUNDING}

None.

\section{AVAILABILITY OF DATA AND MATERIALS}

Not applicable.

\section{ETHICS APPROVAL AND CONSENT TO PARTICIPATE}

Not applicable.

\section{CONSENT FOR PUBLICATION}

Not applicable.

\section{COMPETING INTERESTS}

The authors declare that they have no competing interests. 


\section{REFERENCES}

1. Pham PV, Vu NB. Off-the-shelf mesenchymal stem cells from human umbilical cord tissue can significantly improve symptoms in COVID-19 patients: an analysis of evidential relations. World Journal of Stem Cells. 2020;12(8):721-30. PMID: 32952854. Available from: 10.4252/wjsc.v12.i8.721.

2. Vu NB, Pham PV. Umbilical Cord Tissue-derived Mesenchymal Stem Cells Should be Considered as Adjuvant Therapy for COVID-19 Treatment: An Opinion from Pooled Clinical Evidence. Biomedical Research and Therapy. 2021;8(9):4583-95. Available from: 10.15419/bmrat.v8i9.694.

3. Shi L, Yuan X, Yao W, Wang S, Zhang C, Zhang B. Human mesenchymal stem cells treatment for severe COVID-19: 1-year follow-up results of a randomized, double-blind, placebocontrolled trial. EBioMedicine. 2022;75:103789. PMID: 34963099. Available from: 10.1016/j.ebiom.2021.103789.

4. Chen $H$, Zhang L, He Z, Wang D, Liu L, Zhang W, et al. Systemic administration of human umbilical cord derived mesenchymal stem cells effectively ameliorates the outcomes of a critically ill elderly patient with COVID-19 with multiple comorbidities: A case report. World Academy of Sciences Journal. 2020;2(6):1-1. Available from: 10.3892/wasj.2020.70.

5. Meng F, Xu R, Wang S, Xu Z, Zhang C, Li Y. Human umbilical cord-derived mesenchymal stem cell therapy in patients with COVID-19: a phase 1 clinical trial. Signal Transduction and Targeted Therapy. 2020;5(1):172. PMID: 32855385. Available from: 10.1038/s41392-020-00286-5.

6. Shi L, Huang H, Lu X, Yan X, Jiang X, Xu R. Effect of human umbilical cord-derived mesenchymal stem cells on lung damage in severe COVID-19 patients: a randomized, double-blind, placebo-controlled phase 2 trial. Signal Transduction and Targeted Therapy. 2021;6(1):58. PMID: 33568628. Available from: 10.1038/s41392-021-00488-5.

7. Guo Z, Chen Y, Luo X, He X, Zhang Y, Wang J. Administration of umbilical cord mesenchymal stem cells in patients with severe COVID-19 pneumonia. Critical Care (London, England). 2020;24(1):420. PMID: 32653043. Available from: 10.1186/ s13054-020-03142-8.

8. Fajgenbaum DC, June $\mathrm{CH}$. Cytokine Storm. The New England Journal of Medicine. 2020;383(23):2255-73. PMID: 33264547 Available from: 10.1056/NEJMra2026131.

9. Huang KJ, Su IJ, Theron M, Wu YC, Lai SK, Liu CC. An interferon$\gamma$-related cytokine storm in SARS patients. Journal of Medical Virology. 2005;75(2):185-94. PMID: 15602737. Available from: 10.1002/jmv.20255.

10. Zhu Z, Cai T, Fan L, Lou K, Hua X, Huang Z. Clinical value of immune-inflammatory parameters to assess the severity of coronavirus disease 2019. International Journal of Infectious Diseases. 2020;95:332-9. PMID: 32334118. Available from: 10.1016/j.ijid.2020.04.041.

11. Chen LD, Zhang ZY, Wei XJ, Cai YQ, Yao WZ, Wang MH. Association between cytokine profiles and lung injury in COVID19 pneumonia. Respiratory Research. 2020;21(1):201. PMID: 32727465. Available from: 10.1186/s12931-020-01465-2.

12. Shu L, Niu C, Li R, Huang T, Wang Y, Huang M, et al. Treatment of severe COVID-19 with human umbilical cord mesenchymal stem cells. Stem Cell Research \& Therapy. 2020;11(1):361. PMID: 32811531. Available from: 10.1186/s13287-020-01875-
5.

13. Zengin R, Beyaz O, Koc ES, Akinci IO, Kocagoz S, Sagcan G. Mesenchymal stem cell treatment in a critically ill COVID-19 patient: a case report. Stem Cell Investigation. 2020;7:17. PMID: 33110915. Available from: 10.21037/sci-2020-024.

14. Ercelen NO, Pekkoc-Uyanik KC, Alpaydin N, Gulay GR, Simsek $M$. Clinical experience on umbilical cord mesenchymal stem cell treatment in 210 severe and critical COVID-19 cases in Turkey. Stem Cell Reviews and Reports. 2021;17(5):1917-25. PMID: 34319510. Available from: 10.1007/s12015-021-10214$\mathrm{X}$.

15. Wei F, Kong D, Li T, Li A, Tan Y, Fang J, et al. Efficacy and safety of umbilical cord mesenchymal stem cells for the treatment of patients with COVID-19. Clinics (Sao Paulo). 2021;76:e2604 PMID: 34008772. Available from: 10.6061/clinics/2021/e2604.

16. Hashemian SR, Aliannejad R, Zarrabi M, Soleimani M, Vosough $M$, Hosseini $S E$, et al. Mesenchymal stem cells derived from perinatal tissues for treatment of critically ill COVID-19induced ARDS patients: a case series. Stem Cell Research \& Therapy. 2021;12(1):91. PMID: 33514427. Available from: 10.1186/s13287-021-02165-4.

17. Shcherbak SG, Anisenkova AY, Mosenko SV, Glotov OS, Chernov AN, Apalko SV. Basic Predictive Risk Factors for Cytokine Storms in COVID-19 Patients. Frontiers in Immunology. 2021;12:745515. PMID: 34858403. Available from: 10.3389/ fimmu.2021.745515.

18. Nabahati M. Post-COVID-19 pulmonary fibrosis and its predictive factors: a prospective study. The Egyptian Journal of Radiology and Nuclear Medicine. 2021;52(1):1-7.

19. Dong LH, Jiang YY, Liu YJ, Cui S, Xia CC, Qu C. The antifibrotic effects of mesenchymal stem cells on irradiated lungs via stimulating endogenous secretion of HGF and PGE2. Scientific Reports. 2015;5(1):8713-8713. PMID: 25736907. Available from: 10.1038/srep08713.

20. Takao S, Nakashima T, Masuda T, Namba M, Sakamoto $S$, Yamaguchi $\mathrm{K}$, et al. Human bone marrow-derived mesenchymal stromal cells cultured in serum-free media demonstrate enhanced antifibrotic abilities via prolonged survival and robust regulatory $T$ cell induction in murine bleomycininduced pulmonary fibrosis. Stem Cell Research \& Therapy. 2021;12(1):506. PMID: 34530920. Available from: 10.1186/ s13287-021-02574-5.

21. Li DY, Li RF, Sun DX, Pu DD, Zhang YH. Mesenchymal stem cell therapy in pulmonary fibrosis: a meta-analysis of preclinical studies. Stem Cell Research \& Therapy. 2021;12(1):461. PMID: 34407861. Available from: 10.1186/s13287-021-02496-2.

22. Chen X, Wang F, Huang Z, Wu Y, Geng J, Wang Y. Clinical applications of mesenchymal stromal cell-based therapies for pulmonary diseases: An Update and Concise Review. International Journal of Medical Sciences. 2021;18(13):2849-70. PMID: 34220313. Available from: 10.7150/ijms.59218.

23. d Silva KN, Pinheiro PC, Gobatto AL, da Hora Passos R, Paredes $B D$, de Aragão França $L S$, et al. Immunomodulatory and Anti-fibrotic Effects Following the Infusion of Umbilical Cord Mesenchymal Stromal Cells in a Critically III Patient With COVID-19 Presenting Lung Fibrosis: A Case Report. Frontiers in medicine. 2021;8:767291. Available from: 10.3389/fmed. 2021.767291. 
Ready to submit your manuscript? Choose Biomedpress and benefit from:

- Fast, convenient online submission

- Through peer-review by experienced researchers

- Rapid publication on acceptance

- Free of charge (without publication fees)

Learn more http://www.biomedpress.org/journals/
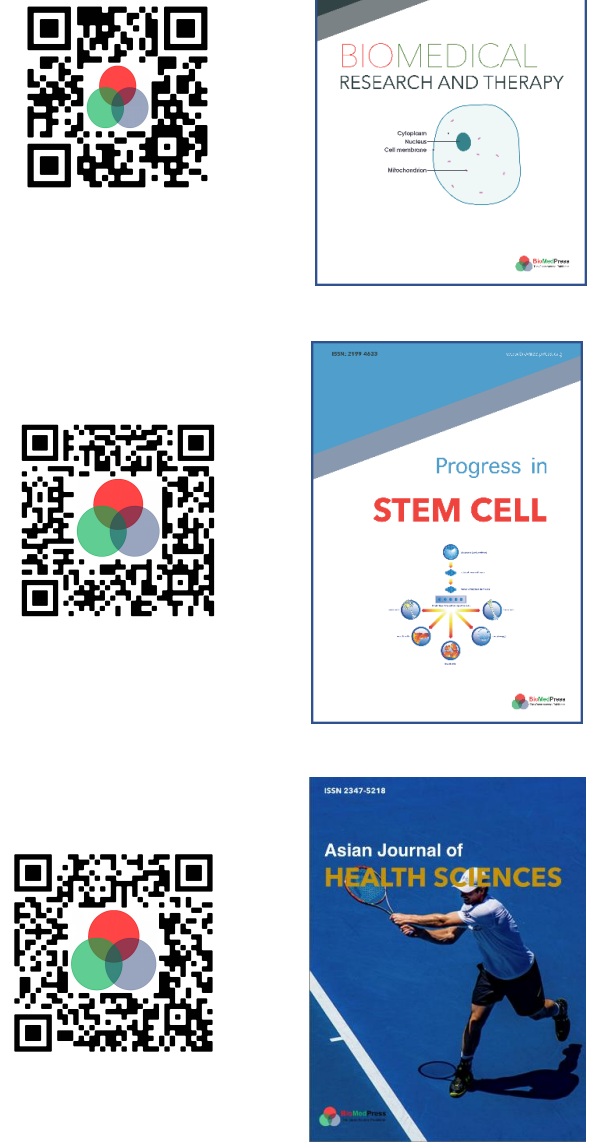

Asian Journal of Health Sciences

ISSN: 2347-5218

Indexed: Google Scholar

Acceptance Rate (2020): 72.89\%

Article Publishing Charge: Free

Submission to first editorial decision: 16.5 days

Biotechnological Research

ISSN: 2395-6763

Indexed: Google Scholar

Acceptance Rate (2020): $67.02 \%$

Article Publishing Charge: Free

Submission to first editorial decision: 28.5 days 